\title{
Konsep Penataan Jalur Pejalan Kaki di Kawasan Taman Gajah, Kota Bandar Lampung
}

\author{
Zenia F Saraswati ${ }^{1 *}$ \\ ${ }^{1}$ Perencanaan Wilayah dan Kota, Jurusan Teknologi Infrastruktur Kewilayahan, Institut Teknologi Sumatera \\ *Penulis Korespondensi: zenia.saraswati@pwk.itera.ac.id; Telp. +62 812-331-5959-3
}

\begin{abstract}
Abstrak:
Kawasan Taman Gajah merupakan guna lahan dikembangkan menjadi Ruang Terbuka Hijau (RTH) dan ruang publik yang mampu mengakomodir kebutuhan masyarakat. Untuk mendukung aksesibilitas pengguna ruang terbuka ini, prasarana transportasi perkotaan menjadi penting untuk diperhatikan terutama prasarana pejalan kaki. Perencanaan prasarana jalur pejalan kaki harus dilakukan berdasarkan kebutuhan pengguna ruang. Penelitian ini ditujukan untuk mengetahui kinerja jalur pejalan kaki dengan mempertimbangkan preferensi dan karakteristik pengguna. Pada sebagian besar ruas jalur pejalan kaki di Kawasan Taman Gajah terdapat hambatan samping yang terdapat pada jalur pejalan kaki diantaranya adalah kerusakan jalur pejalan kaki, parkir kendaraan pada jalur, serta keberadaan pedagang kaki lima (PKL). Hal ini menyebabkan masih banyak pejalan kaki yang melakukan perjalanannya di badan jalan. Juga diketahui dari perspektif pengguna, bahwa sebagian besar pengguna jalur pejalan kaki melakukan perjalanan dengan tujuan rekreasi. Pengguna jalur pejalan kaki di kawasan Taman Gajah juga ternyata merupakan pejalan kaki dengan perjalanan turunan yang sebelumnya menggunakan sepeda motor. Penataan jalur pejalan kaki di Kawasan Taman Gajah harus memperhatikan pedagang kaki lima (PKL) sebagai daya tarik kegiatan yang tidak mengganggu lalu lintas pejalan kaki juga lebih mendorong penggunaan kendaraan umum.
\end{abstract}

Kata Kunci: Jalur pejalan kaki; persepsi pengguna; desain

\section{Latar Belakang}

Kawasan Taman Gajah merupakan ruang publik yang terdiri atas RTH (Ruang Terbuka Hijau), pasar seni, stadion olahraga indoor dan lapangan olahraga outdoor. Terletak pada pusat kota Bandar Lampung, Kawasan Taman Gajah dikelilingi oleh guna lahan dengan intensitas yang tinggi. Berada diantara koridor Jalan Majapahit, Jalan Sriwijaya Jalan Jendral Sudirman dan Jalan Tulang Bawang yang memiliki tata guna lahan perdagangan dan jasa. Menurut Rencana Tata Ruang Wilayah (RTRW) Kota Bandar Lampung Tahun 2010-2030, kawasan Taman Gajah akan dikembangkan menjadi RTH (Ruang Terbuka Hijau) dan ruang publik yang dapat mengakomodir aktivitas dan kebutuhan masyarakat.

Dalam pengembangan wilayah, prasarana transportasi merupakan hal yang penting dalam mendukung pergerakan manusia atau barang. Keberadaan prasarana transportasi harus mampu melayani setiap penggunanya. Jalur pejalan kaki sebagai bagian dari prasarana transportasi perlu diperhitungkan keberadaannya karena dengan berjalan kaki merupakan salah satu bagian dari kegiatan transportasi (Tamin, 2000). Namun pengembangan transportasi tentu saja tidak boleh melupakan karakteristik penggunanya. Dalam Pedoman Penyediaan dan Pemanfaatan Prasarana dan Sarana Ruang Pejalan Kaki di Perkotaan (2008) dijelaskan pemerintah dalam merencanakan, membangun, dan memelihara ruang pejalan kaki dapat melibatkan masyarakat. Wujud peran masyarakat adalah dengan bantuan pemikiran atau pertimbangan berkenaan dengan kebijakan penyediaan dan pemanfaatan sarana dan prasarana di ruang pejalan kaki.

Dalam upaya memenuhi kebutuhan sarana prasarana, menjadi penting utnuk melihat kondisi eksisting serta karakteristik penggunanya. Penelitian ini ditujukan untuk melihat gap antara kondisi eksisting prasarana jalur pejalan kaki, serta memberikan penekanan pada elemen yang perlu diperhatikan sesuai dengan karakteristik pengguna jalur pejalan kaki tersebut. Adanya penelitian ini dapat digunakan sebagai masukan dan pertimbangan untuk konsep penataan jalur pejalan kaki khususnya di kawasan Taman Gajah. 


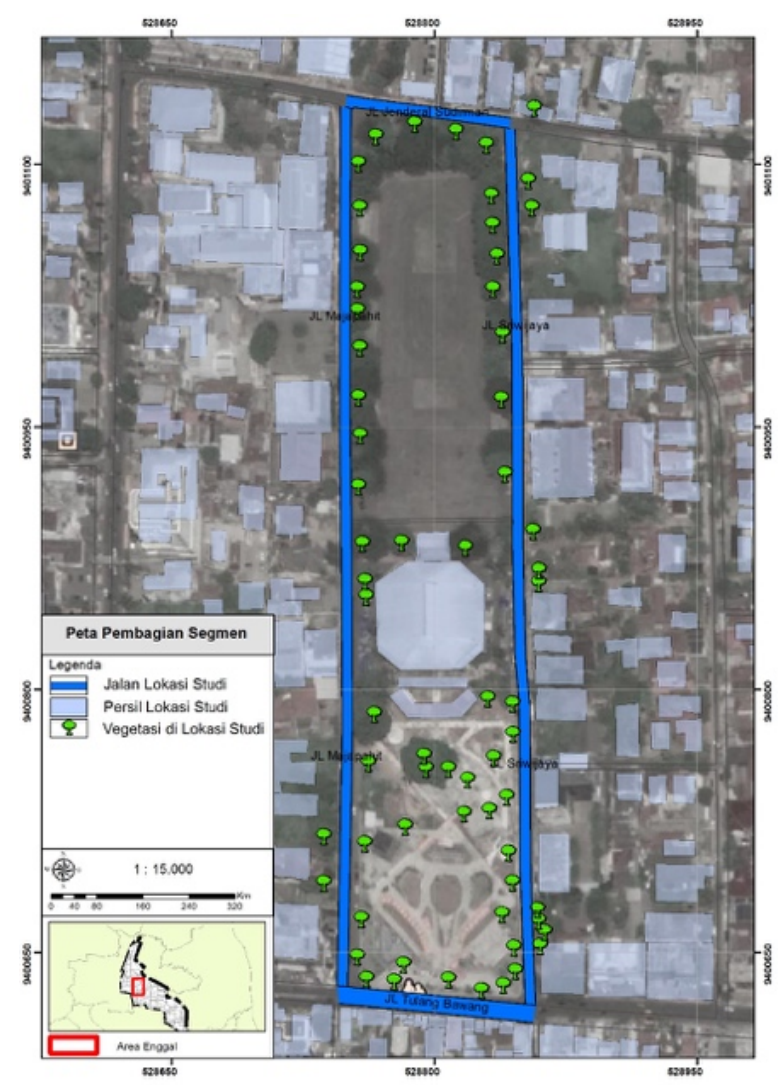

Gambar 1. Lokasi Penelitian

\section{Metode}

Penelitian ini menggunakan metode penelitian deskriptif kuantitatif dan kualitatif. Penggambaran secara deskriptif dalam penelitian ini dilakukan untuk menggambarkan kondisi yang terjadi dalam pengamatan. Pengamatan kualitatif ditujukan untuk mengunggap melalui model matematis (Arikunto, 2010), sedangkan pengamatan kualitatif dilakukan karena peneliti ingin mengeksplor fenomena-fenomena yang tidak dapat dikuantifikasikan seperto konsep yang beragam, karakteristik suatu barang dan jasa, gambar- gambar, model fisik suatu artifak dan lain sebagainya (Satori, 2013).

\subsection{Metode Pengumpulan Data}

Penelitian ini menggunakan data primer yang dikumpulkan melalui metode kuesioner dan observasi lapangan. Metode kuesioner diberlakukan kepada pengguna jalur pejalankaki. Adapun pertanyaan yang disampaikan pada kuesioner adalah: usia, tujuan pejalan kaki, moda transportasi yang digunakan pejalan kaki serta minat pejalan kaki untuk menggunakan jalur pejalan kaki. Pembagian kuesioner dibagi dalam rentang waktu temporal pagi (07.0008.00), siang (12.00-13.00) dan sore (17.00-18.00). Survei kuesioner juga dilakukan baik pada hari kerja maupun weekend untuk memastikan keholistikan pada data yang diambil. Observasi lapangan dilakukan untuk memberikan gambaran kondisi eksisting dari objek pengamatan, dalam hal ini penggunaan lahan dan kondisi jalur pejalan kaki.

\subsection{Metode Analisis Data}

Analisis data dilakukan dengan metode deskripsi dengan menjelaskan keadaan eksisting melalui grafik serta gambar pendukung.

\section{Hasil dan Pembahasan}

Pembahasan ini dibagi menjadi lima bagian, penggunaan lahan, karakteristik pengguna jalur pejalan kaki, hambatan jalur pejalankaki, dan minat pejalan kaki terhadap jalur pejalan kaki

\subsection{Penggunaan Lahan}

Penggunaan lahan yang ada di koridor kawasan Taman Gajah merupakan RTH yang dilengkapi dengan sarana olahraga. Taman Gajah dikelilingi oleh berbagai penggunaan lahan dengan intensitas yang tinggi antara lain dengan guna sosial budaya, permukiman dan perkantoran serta perdagangan dan jasa. Gambar 2 menunjukkan persebaran guna lahan di Kawasan Taman Gajah 


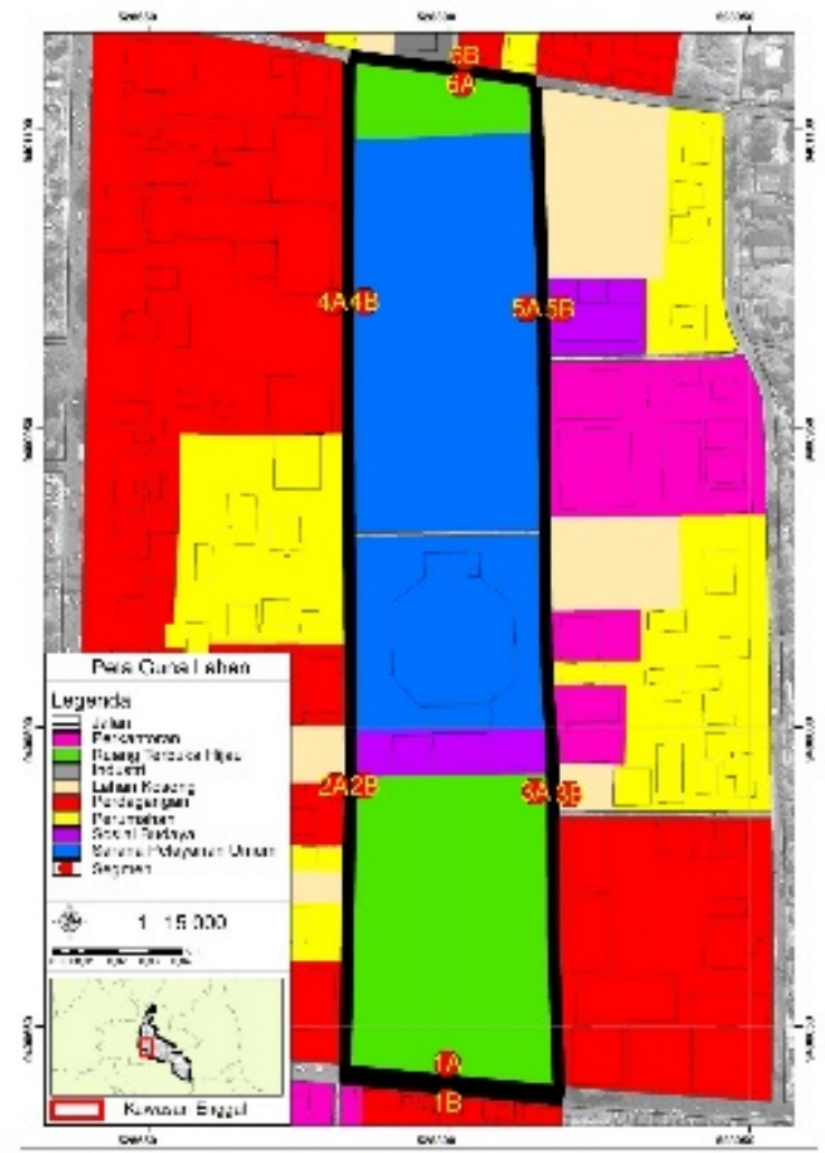

Gambar 2. Peta Guna Lahan Kawasan Taman Gajah

\subsection{Karakteristik Pengguna Jalur Pejalan Kaki}

Melalui identifikasi karakteristik pejalan kaki maka dapat diketahui penggunaan jalur pejalan kaki dan dapat menggambarkan kinerja jalur pejalan kaki yang ada di Kawasan Taman Gajah Dapat dilihat pada Gambar 3 ratarata usia pejalan kaki yang mendominasi adalah pejalan kaki dengan usia antara 16-20 tahun yaitu sebesar 41,7\% mengingat pada kawasan Taman Gajah terdapat sarana fasilitas gym, sarana perdagangan dan jasa berupa Mall Plaza Lotus, dan Taman Gajah. Kemudian nilai prosentase pejalan kaki kedua adalah pejalan kaki dengan usia 2135 tahun mengingat adanya sarana olahraga dan taman untuk bersantai.

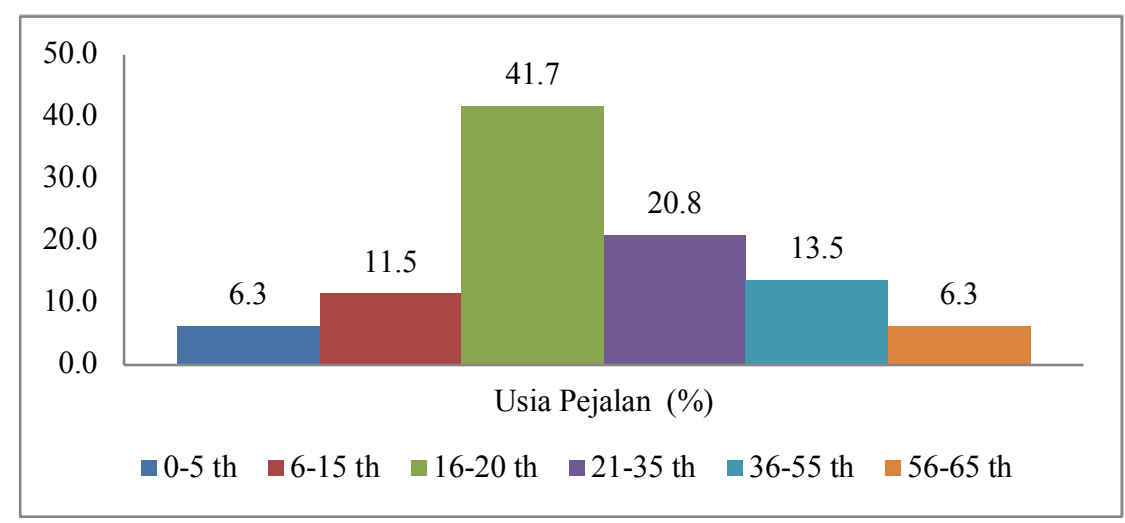

Gambar 3. Persentase Usia Pejalan Kaki di Koridor Kawasan Taman Gajah

Secara keseluruhan pejalan kaki yang berjalan di Kawasan Taman Gajah yaitu untuk melakukan kegiatan menuju Lapangan Merah Enggal atau rekreasi. Pejalan kaki yang ada umumnya memang bertujuan untuk menuju kawasan Taman Gajah untuk hanya sekedar berjalan-jalan. Presentase tujuan dari pejalan kaki ditunjukkan pada Gambar 4. 


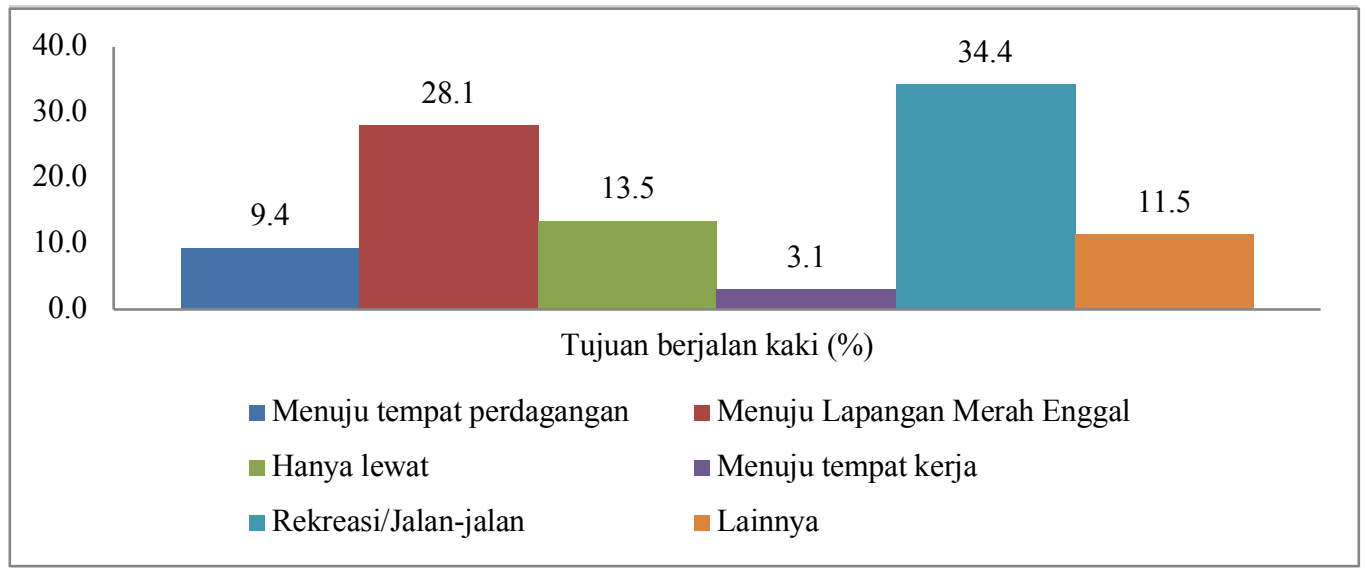

Gambar 4. Persentase Tujuan Pejalan Kaki yang Berjalan Kaki di Koridor Kawasan Taman Gajah

Moda yang digunakan oleh pejalan kaki sebelum berjalan kaki yaitu rata-rata adalah menggunakan sepeda motor. Untuk presentase moda yang digunakan sebelum dan sesudah berjalan kaki dapat dilihat pada Gambar 5 dan Gambar 6 .

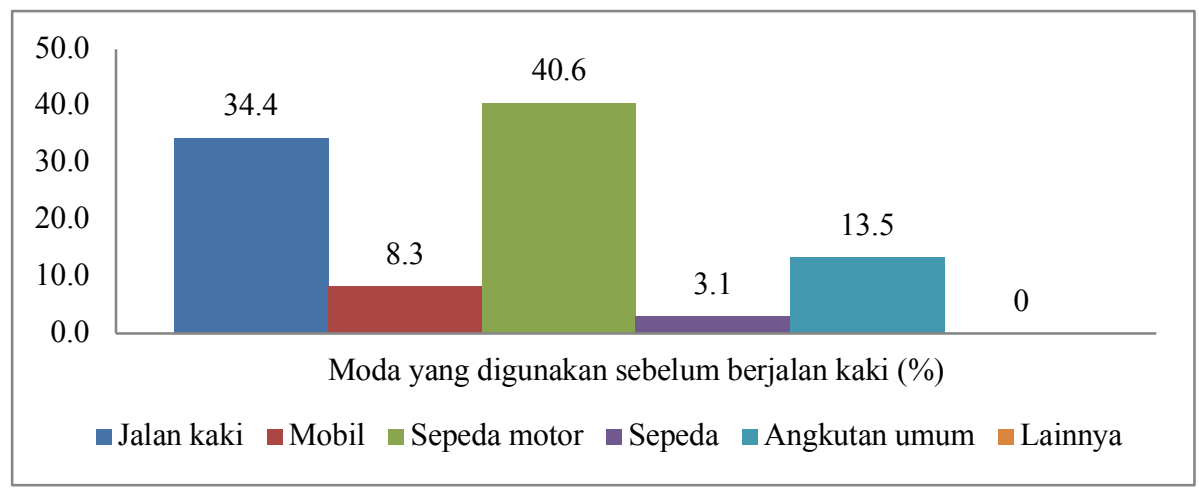

Gambar 5. Persentase Moda yang Digunakan Oleh Pejalan Kaki Sebelum Berjalan Kaki di Koridor Kawasan Taman Gajah

Sedangkan moda yang digunakan setelah berjalan kaki, rata-rata pejalan kaki menggunakan sepeda motor. Berdasarkan hasil dari jenis moda yang digunakan sebelum dan sesudah berjalan kaki, dapat dilihat bahwa sebagian besar pejalan kaki termasuk kategori pejalan kaki pemakai kendaraan pribadi penuh, yaitu mereka yang menggunakan kendaraan pribadi sebagai moda awal dan sesudah berjalan serta berjaan kaki digunakan sebagai moda antara tempat perkir menuju tempat tujuannya.

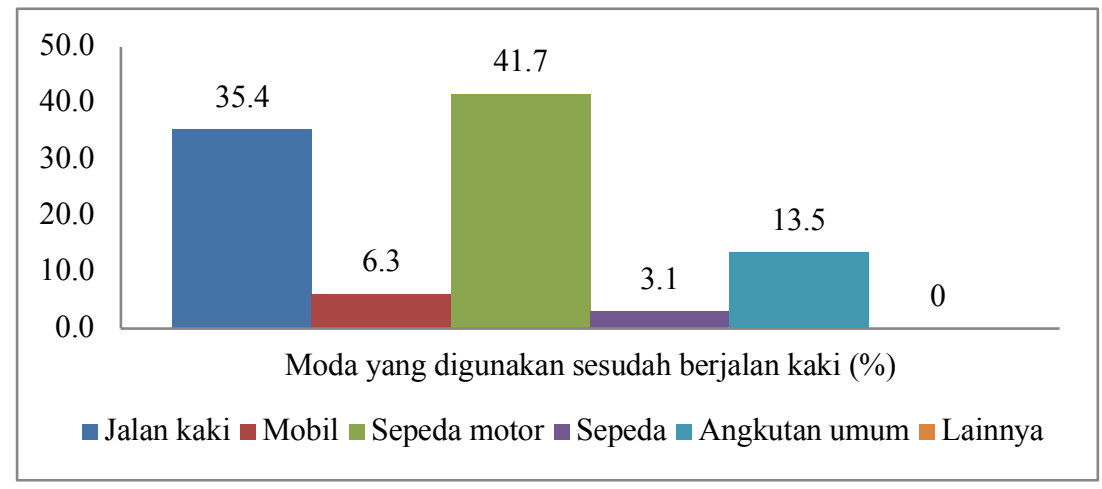

Gambar 6. Persentase Moda yang Digunakan Oleh Pejalan Kaki Setelah Berjalan Kaki di Koridor Kawasan Taman Gajah 


\subsection{Hambatan di jalur pejalan kaki}

Hambatan yang sering ditemukan pada jalur pejalan kaki di koridor Kawasan Taman Gajah adalah kegiatan non pejalan kaki yaitu keberadaan pedagang kaki lima (PKL) yang berjualan di atas jalur pejalan kaki, parkir kendaraan diatas jalur pejalan kaki, pembeli dari PKL yang memanfaatkan jalur pejalan kaki sebagai tempat duduk atau tempat nongkrong dan PKL yang memasang kursi diatas jalur pejalan kaki untuk duduk pelanggannya. Dikarenakan adanya hambatan tersebut maka dari itu lebar efektif jalur pejalan kaki yang tersedia menjadi berkurang dan mengganggu bagi sirkulasi pejalan kaki yang melintasinya.

Kondisi perparkiran di koridor Kawasan Taman Gajah terdapat parkir on street atau parkir di badan jalan dan juga terdapat parkir off street atau parkir diluar badan jalan. Parkir off street yang ada berupa fasilitas parkir sebagai fasilitas penunjang yang disediakan oleh bangunan utama yang berkegiatan tersebut, sedangkan parkir on street biasanya terdapat di Jalan Majapahit dan Jalan Sriwijaya yaitu tepatnya disekitar Lapangan Merah Enggal yaitu di segmen 2 dan segmen 3 karena masyarakat umumnya senang untuk mengunjungi tempat tersebut untuk dudukduduk dan nongkrong. Keberadaan PKL yang berjualan diatas jalur pejalan kaki sebenarnya dilarang dan sudah disediakan tenda untuk berjualan di dalam Lapangan Merah Enggal namun masih banyak ditemukan keberadaan PKL yang menempati trotoar koridor Kawasan Taman Gajah.

Tidak hanya hambatan, kualitas jalur pejalan kaki di Kawasan Taman Gajah juga buruk. Terdapat kerusakan perkerasan pada jalur pejalan kaki juga menjadi faktor yang mempengaruhi pada penggunaan jalur pejalan kaki oleh para pejalan kaki. Pada setiap ruas jalur pejalan kaki di Kawasan Taman Gajah, terdapat kerusakan perkerasan yang mengakibatkan jalur pejalan kaki sulit untuk digunakan.

\subsection{Minat Pejalan Kaki terhadap Jalur Pejalan Kaki}

Dari hasil penyebaran kuisioner yang telah dilakukan diperoleh informasi bahwa sebagian besar pejalan kaki menyukai trotoar untuk berjalan kaki, namun sebagian pejalan kaki lebih memilih berjalan kaki di badan jalan dikarenakan keadaaan trotoar yang ditempati oleh PKL untuk berjualan serta parkir motor diatasnya sehingga tidak ada ruang lagi bagi pejalan kaki untuk berjalan kaki. Presentase minat pejalan kaki untuk berjalan kaki di trotoar atau badan jalan sebagai tempat yang dipilih oleh pejalan kaki dalam berjalan dapat dilihat pada Gambar 9.

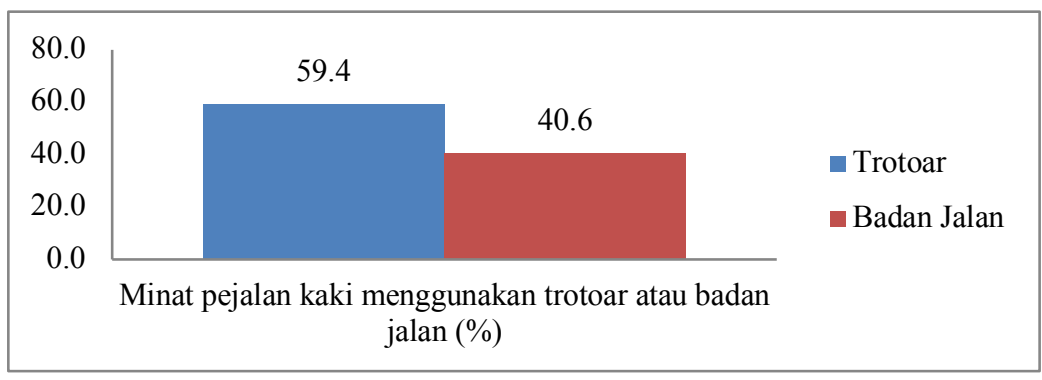

Gambar 7. Persentase Minat Pejalan Kaki untuk Menggunakan Trotoar atau Badan Jalan Saat Berjalan Kaki di Koridor Kawasan Taman Gajah

Terlihat bahwa masih terdapat $40.6 \%$ pejalan kaki memilih untuk menggunakan badan jalan untuk berjalan kaki. Mengingat mayoritas pejalan kaki berusia muda, hal ini menunjukkan tingkat kesulitan yang masih tinggi untuk menggunakan jalur pejalan kaki untuk berjalan. Untuk mengurangi keberadaan pejalan kaki di badan jalan, tentu saja peningkatan kualitas jalur pejalan kaki di perlukan di Kawasan Taman Gajah.

\subsection{Rekomendasi Pengembangan Jalur Pejalan Kaki}

Pengembangan jalur pejalan kaki secara intrinsik haruslah mengedepankan kepentingan pejalan kaki. Hal ini dapat dilakukan dengan memperbaiki kerusakan pada perkerasan jalur pejalan kaki serta mengaplikasikan kebutuhan minimum lebar jalur pejalan kaki yakni 1.5 tanpa hambatan apapun (Dirjen Penataan Ruang, 2008). Namun upaya dalam melakukan pengembangan ini perlu mempertimbangkan karakteristik dari pengguna jalur pejalan kaki.

Terilhat pada Gambar 2, guna lahan di sekitar Kawasan Taman Gajah memiliki dayatarik yang tinggi, memberikan volume pejalan kaki yang lebih tinggi daripada daerah sekitarnya. Berdasarkan Gambar 4, terlihat bahwa tujuan utama pejalan kaki untuk berada di Kawasan Taman Gajah adalah berekreasi. Berdasarkan hasil observasi, salah satu bentuk rekreasi yang dimaksud adalah nongkrong PKL. Hal ini membuat penataan PKL menjadi prioritas utama. Selain itu pada Gambar 5 dan Gambar 6 terlihat bahwa motor untuk mencapai Kawasan Taman Gajah, mayoritas pejalan kaki menggunakan sepeda motor. Hal ini menjadi masalah tersendiri terutama dengan merebaknya penyalahgunaan jalur pejalan kaki sebagai tempat parkir motor. Pengembangan fasilitas yang 
lebih mendukung kendaraan umum diperlukan untuk mengatasi permasalahan ini. Ilustrasi dari rekomendasi ini dapat terligat pada Gambar 8.
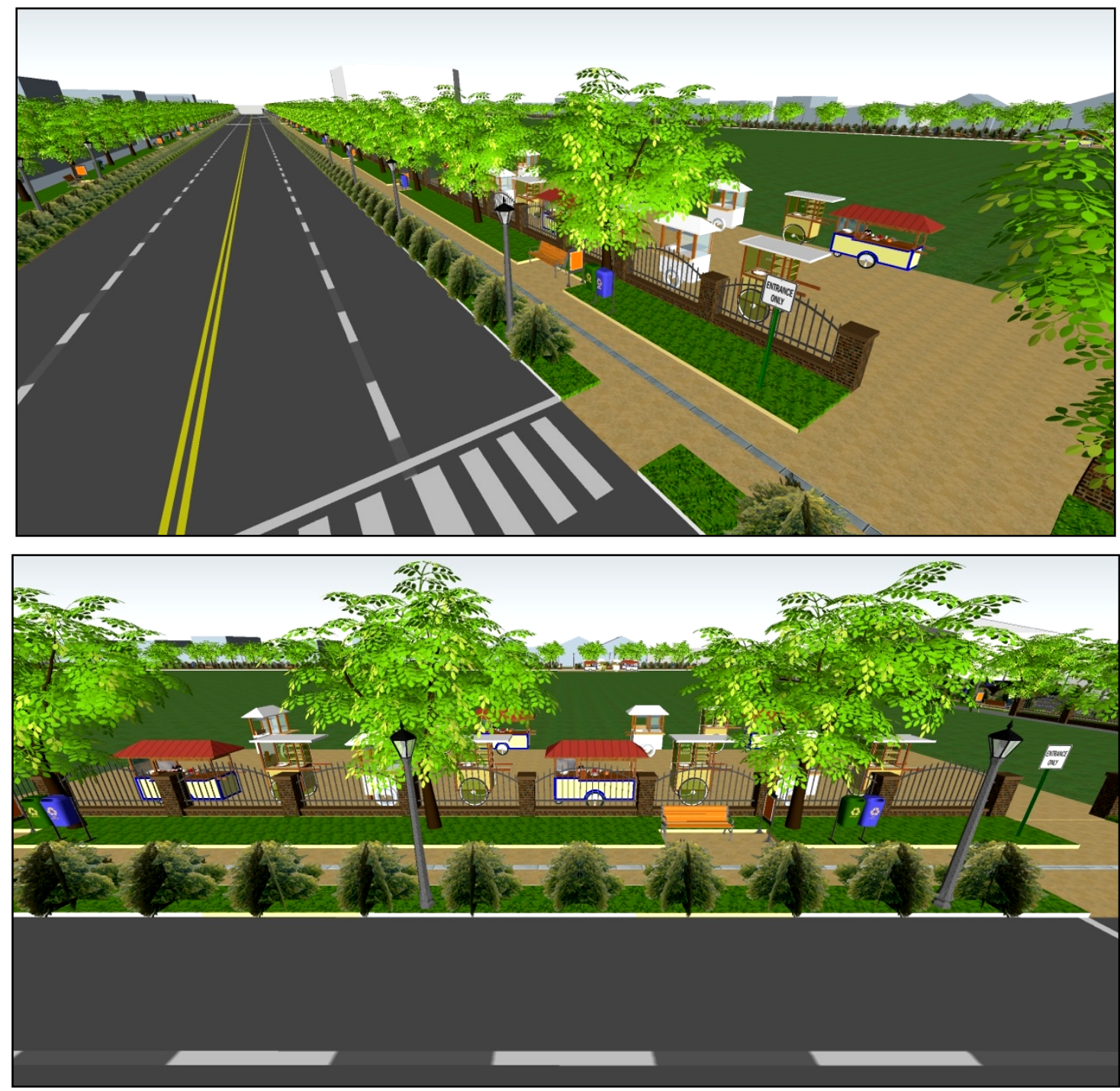

Gambar 8. Ilustrasi Hasil Akhir Penataan Jalur Pejalan Kaki Kawasan Taman Gajah

\section{Kesimpulan}

Pengembangan jalur pejalan kaki perlu dilakukan mengingat kualitas jalur pejalan kaki di Kawasan Taman Gajah buruk dengan kerusakan perkerasan di setiap ruas jalur pejalan kaki. Selain itu, pengembangan jalur pejalan kaki di Kawasan Taman Gajah perlu diperhatikan mengenai penataan PKL dan peningkatan fasilitas yang mendukung penggunaan kendaraan umum. Dalam upaya pengembangan jalur pejalan kaki di Kawasan Taman Gajah, juga diperlukan penelitian lanjutan mengenai analisis stakeholder yang terkait dalam pengembangan jalur pejalan kaki

\section{Daftar Pustaka}

Arikunto, Suharsimi. 2010. Prosedur Penelitian Suatu Pendekatan Praktik. Yogyakarta: Rineka Cipta.

Dirjen Penataan Ruang Departemen Pekerjaan Umum. 2008. Pedoman Penyediaan dan Pemanfaatan Prasarana dan Sarana Ruang Pejalan Kaki di Perkotaan. Jakarta: Dirjen Penataan Ruang.

Rencana Tata Ruang Wilayah (RTRW) Kota Bandar Lampung Tahun 2010-2030. Badan Perencanaan dan Pembangunan Daerah Kota Bandar Lampung.

Satori, Djam'an dan Komariah, Aan. 2013. Metodologi Penelitian Kualitatif. Bandung. Alfabeta.

Tamin, Ofyar Z. 2000. Perencanaandan Permodelan Transportasi. Bandung: Penerbit ITB. 